Valóságos könyvtár - könyvtári valóság. Könyvtár- és információtudományi tanulmányok 2018. Szerk. Kiszl Péter, Csík Tibor.

Budapest, ELTE BTK Könyvtár- és Információtudományi Intézet. 2018. 329-335.

\title{
ELEKTRONIKUS PLATFORMOK AZ OKTATÁSBAN ÉS A KÖNYVTÁRAK VÁLTOZÓ SZEREPE
}

\author{
NEMES LÁSZLÓ \\ Magyar Információtudományi Alapítvány, kuratóriumi elnök
}

\section{TARTALMI ÖSSZEFOGLALÓ}

A felsőoktatási szektorban egyre dominánsabbak a jelenlétet nem, vagy csak minimálisan igénylő távoktatási formák. Bár az elektronikus tananyagok, valamint az e-learning keretrendszerek több mint másfél évtizede jelen vannak az oktatásban, az utóbbi években történt széles körű, a mindennapokban is észlelhető technikai ugrás azt eredményezte, hogy immár nem csak szigetszerúen használhatják őket. Az oktatáshoz mindig is hozzá tartoztak a tananyagokat, a kutatáshoz szükséges szakirodalmat, valamint forrásokat gondozó könyvtárak. Összefoglalom az elektronikus tananyagok fajtáit, felépítési lehetőségeit, a könyvtárak szerepét az e-learning folyamatában, valamint bemutatok fejlesztési lehetőségeket. Az összefoglaló alapját képező alkalmazott kutatás aktualitását több már folyó vagy a jövőben induló fejlesztés adja.

\section{Az oktatás célja, feladata és változásai a digitális robbanás tükrében}

Oktatás alatt azt a folyamatot, társadalmi rendszert értjük, amelynek keretében a társadalom tagjai generációról generációra tovább örökítik a megszerzett tudást, ezzel biztosítva az adott közösség kulturális újratermelését. E folyamat során azonban nemcsak a kulturális tudás - az adott csoport fennmaradásához szükséges tapasztalat, norma, ismeret (azaz olyan tudáselemek, amelyek ismerete a közösség működéséhez szükséges) öröklődik át, hanem az egyéni személyiség fejlődése is bekövetkezik. ${ }^{1}$ Igy az oktatás mind társadalmi, mind egyéni téren hasznos, fejlesztô folyamat, azonban fontos megjegyezni, hogy nem az egyetlen e célt szolgáló társadalmi rendszer, többek között a nem formalizált keretek között zajló tudásreprodukció is nagy fontossággal bír, amelyhez szintén kapcsolódhatnak információs szolgáltatások.

Az oktatásnak különböző szintjeit és formáit különítjük el, azonban mindegyikhez szükséges egy rendezett alapokon nyugvó információ- és tudásvagyont menedzselő, illetve azt szolgáltató szervezet és/vagy rendszer. E rendszer öltsön akár virtuális, akár fizikai valójában létező formát, lehet önálló vagy integrált, mint esetünkben a könyvtári rendszer. Véleményem szerint azonban a jövőben ez különböző gyűjteménytípusokat (könyvtár, levéltár, múzeum) magába integráló platform lesz. Ahhoz, hogy ezen állításomat alátámasszam, a következőkben bemutatom az oktatás szintjeit, formái közül külön kiemelve a távoktatást, amely új lendületet adott nemcsak az oktatás tárgyát képező 


\section{NEMES LÁSZLÓ}

objektumok, hanem magának az oktatás folyamatának digitalizálásához is. A távoktatás elterjedése maga után vonta, illetve a jövőben maga után kell, hogy vonja a hozzá kapcsolódó információs szolgáltatások fejlődését is.

Az oktatás szintjeinek egyértelmű definiálására mind hazánkban, mind Európa országaiban, illetve országok felett átnyúlóan is különböző keretrendszereket dolgoztak ki, amelyek a nemzeti, valamint a lokális különbségek ellenére egyértelmúen azonosíthatóan írják le az oktatási rendszereket. Akár a 2015-ben elfogadott Magyar Képesítési Keretrendszerre (MKKR), akár más országok képesítési rendszereire, illetve az Európai Képesítési Keretrendszerre (EKKER), vagy akár az UNESCO által jóváhagyott az Oktatás Egységes Nemzetközi Osztályozási Rendszerére (ISCED) tekintünk, a felsőoktatásban nyújtott képzések egyértelműen a képzési rendszer csúcsát jelentik: nemcsak az átadott tananyagok mennyisége növekszik, hanem azok rendezettsége is. A felsőoktatásban információs szempontból már nem feltétlenül csak az információk és a tudás átadásáról beszélünk, hanem az új tudás létrehozásának elvárt képességéről is.

E képzési keretrendszerek szintjei között a felsőoktatásban érintett szintekhez kapcsolódva helyezem el a távoktatást. E szűkítésnek az az oka, hogy hazánkban az egyéni tanrenden kívül a köznevelést lefedő képzési szinteken (MKKR 1-4. szint) nem jellemző a távoktatás, viszont a felsőoktatásban, illetve a felnőttképzésben egyre markánsabb teret kap a jelenléti képzések, képzésrészek csökkentése. Ennek fényében a nemzeti felsőoktatásról szóló 2011. évi CCIV. törvény (továbbiakban Nftv.) 108. \-ban található fogalomtárának meghatározását használom, amikor távoktatásról írok. E szerint a „távoktatás: sajátos információ-technológiai és kommunikációs taneşközök, valamint ismeretátadási-tanulási módszerek, digitális tananyagok használatával az oktató és hallgató interaktiv kapcsolatára és az önálló hallgatói munkára épülo" képzés, amelyben a tanórák száma nem éri el a teljes idejü képzés tanóráinak harminc százalékát." E fogalom-meghatározásban a távoktatás immár nem az esti, illetve a levelező képzések alternatív elnevezése, hanem külön képzési forma lett. Szintén a definícióban szerepel, hogy a távoktatás felfutása nem választható el az informatikai fejlődés ezredforduló után felgyorsuló ütemétől. A távoktatás korábban is létezett, ha annak tekintjük a levelező képzést, ugyanakkor a digitális platformok megjelenésével ennek módszertana, eszköztára és elvei is folyamatos változáson mennek keresztül.

A távoktatás fontos jellemzője, hogy a tanuló önállóságára épít, az oktatóval való kapcsolata közvetetté válik, így a tanulási folyamat másképpen alakul, ${ }^{2}$ ezáltal a szükséges tudás- és információvagyon feltérképezésében is a nagyobb önállóságon van a hangsúly.

A távoktatás fejlődéstörténetében is megfigyelhetőek a változások és az ugrások, az 1990-es évek végén ezzel a magyar felsőoktatási és könyvtári szakirodalom is foglalkozott, azonban a lehetőségek teljesen megváltoztak húsz év alatt. Míg az 1998-ban hazánkban is elindult LISTED projekt célja a közkönyvtárak bevonása volt az önálló tanulás, valamint a korszerú információs technológia eszközeivel segített nyitott és távoktatás támogatásának rendszerébe, ${ }^{3}$ ma már a távoktatási formák nem képzelhetőek el 
úgynevezett e-learning keretrendszerek nélkül. Így már nem csak a nyugodt környezet biztosítása a könyvtár feladata.

Az e-learning fogalmának számos definíciója van. Ennél is nagyobb számú azonban az intézmények gyakorlata. A közös pontok a következőkben foglalhatók össze:

1. a tananyagokat elektronikusan tárolják és az interneten érhetők el a hallgatók számára;

2. biztosítják az oktató-hallgató kommunikáció lehetőségét;

3. mindezek egy keretrendszerben valósulnak meg, amely ezáltal formai kritériumok közé szorítja a tananyagokat.

A különbségek már ott jelentkeznek, hogy a tananyagok milyen elemeket tartalmaznak, milyen fokú az interaktivitásuk, milyen módon készülnek, mennyire igényelnek speciális környezetet. E különbségek a könyvtári szolgáltatásokra is hatással vannak. Hiszen kérdés, hogy műnek, szellemi terméknek tekinthető-e az e-learning tananyag, illetve hogy az intézmény mennyire szeretné a visszakereshetőséget biztosítani. Így ebben a képzési módban az intézmények elektronikus könyvtári szolgáltatásaira helyeződik a hangsúly, hiszen a kontakt órákat minimálisan látogató hallgató a könyvtárba még kisebb eséllyel látogat el. Az e-learning könyvtárakkal kapcsolatban 2007-ben a Tudományos és Müszaki Tájékoztatás hasábjain jelent meg Czeglédi László cikke E-learning könyvtár: a fogalom és a megvalósitás címmel. ${ }^{4}$

Az elmúlt tíz évben a környezet jelentôsen átalakult, megváltozott az e-learning gyakorlati megvalósítása, amely nemcsak a technikai megoldások változását foglalja magában, hanem az elérhetőség kiterjedését is. Mára az internet mindennapos használata az e-alkalmazások elérhetőségét is megváltoztatta. Ahhoz, hogy ezek könyvtári vonatkozásait áttekinthessük, szükséges tisztázni, mit tartalmaznak az e-learning rendszerek. Alapvetően két területen találunk tartalmakat ezekben a rendszerekben. Egyrészt itt történik a tanulási környezet biztosításához szükséges információk rendszerezett tárolása, ez magában foglalja a nem tananyag objektumokat is: például naplótartalmakat, fórumokat, kurzusokhoz kapcsolódó oktatásszervezési információkat. Másrészt az e-learning anyagokhoz tartoznak a tananyagokat tartalmazó rendszerek is. Utóbbi esetében több megközelítési és fejlesztési irányról beszélhetünk, attól függően, hogy egyegy tananyag oly mértékben össze van füzve, hogy alkotó elemeik nem használhatók fel újra, vagy a tananyag elemek (learning asset) újra felhasználhatóak, és belőlük újabb és újabb nagyobb tananyag egységek (learning object) alkothatók. Ez utóbbi kérdés az információmenedzsment szempontjából különösen fontos. Mindkét esetben igaz az, hogy az e-learning anyagok nem önmagukban léteznek, hanem egy keretrendszerrel, egy lejátszó alkalmazással együtt, ami biztosítja számukra a megfelelő környezetet. Ezen elektronikus keretrendszerekben használhatóak a tananyagok, jönnek létre virtuálisan a tanulócsoportok, történik a kommunikáció és az értékelés. E rendszereknek van publikus és szerkesztô felülete. Használatuk során a tananyagok tárolása révén könyvtári jellegű, a kommunikációs és felhasználói tevékenység logolása révén levéltári jellegű, valamint adatbázisokba rögzítendő objektumok jönnek létre. 


\section{NEMES LÁSZLÓ}

Tanulmányomban nem célom konkrét rendszerek, mint például a Moodle vagy a közigazgatási továbbképzésben is használt Pro Bono elemzése. Ugyanakkor több olyan kulcsváltozást érdemes megemlíteni, amelyek az elmúlt években jelentek meg e téren. Azt azonban hozzá kell tenni, hogy a változás igen gyors. Egy személyes példát mutatnék be: valamikor 2006-2007 folyamán olyan egyetemi képzésen vettem részt, amelyen „e-learninget” használtunk, nem is egy kurzuson, és nem is csak egy fajtát. Már akkor igen széles volt az a kör, amit az e-learning alatt értettek a kurzusokat szervező oktatóink, a keretrendszerekbe feltöltött órai prezentációktól az oktatási adminisztrációt, fórumot biztosító kurzusokig.

A keretrendszerek egyre szélesebb körű használata maga után vonta, hogy e-tananyagok készítésére is szabványokat alakítottak ki.

Ahhoz, hogy az e folyamatokban használt képzési formákhoz kapcsolódó könyvtári szerepeket számba tudjuk venni, szükséges a digitális környezetben való tanulás jelenlegi két alapfogalmával, a blended learninggel és a MOOC-kal - mélyebben megismerkedni.

- A bleanded learninget vegyes képzésként fordíthatjuk le, neve elárulja jellegét. Egyesíti magában az elektronikus keretek között zajló, valamint a jelenléti képzést, azzal a céllal, hogy mindkét módszer leghasznosabb elemeit használja fel, ennek okán nevezik még mixed mode learningnek, dual mode curriculanak vagy distributed learningnek is. Ebből fakadóan általában olyan képzéseknél használható eredményesen és hatékonyan, amelynek van elméleti és gyakorlati oldala is. E forma is több változáson ment keresztül. A Digitális Tankönyvtárban is idézett definíciója szerint a blended learning ,olyan oktatási technológia, mely a képzéshez változatos, tanulási környezeti elemek (módszerek és esžözö̈k) - hagyományos és virtuális tanulási formák, személyes és távolsági konzultáció biz̨tositásával, nyomtatottés elektronikus tananyagok segitségével magas-szinvonalú (hi-tech) infokommunikációs eszközö̈k révén a tananyagot kooperativan, változatos módszerekkel, egyénre szabott formában teszi hozzáférhetóvé, biztositja a tanulók elörehaladási ütemének ellenôrzését, értékelését." ${ }^{5}$ Azt, hogy mit tekintünk magas színvonalú infokommunikációs eszköznek, mást jelentett tíz éve, amikor ebbe a kategóriába még besorolható volt akár a DVD is, amelyet postázva elküldték az aktuális tananyagot, és mást jelent ma, amikor már arról beszélünk, hogy pár éven belül országos szinten teljes egészében $5 \mathrm{G}$ hálózati lefedettséget érünk el. E módszertan egyik kiemelt velejárója az önálló tanulás, ezáltal az önálló információkeresés is.

- A $M O O C$-ok elterjedése néhány éve kezdődött. A rövidítés feloldása Massive Open Online Course, és a tömeges jelző nem pár száz, hanem több ezer, tízezer résztvevőt jelent egy-egy kurzuson. E kurzusok elterjedése jelentősen átalakította a képzések teljesítéséről alkotott fogalmainkat. Ezen oktatási forma létrejöttének oka az volt, hogy egyes országokban az időjárás megnehezítette nagyobb távolságokról a kurzusok résztvevőinek fizikai megjelenését. A technikai fejlődés viszont lehetővé teszi az online lebonyolítást. Ezen kurzusok nyitottsága az élethosszig tartó tanulást segíti, hiszen feltételekhez nem kötik őket, ugyanakkor nem biztos, hogy ingyenesek. A kurzusok teljesítési 
aránya nem hasonlítható össze a hagyományos kurzusokéval: átlagban 10-15 százalék körül mozog. Az elemzések rámutattak arra, hogy a résztvevők egyik jellemző magatartása, hogy a számukra releváns, őket érdeklő részek megtekintése után nem végzik el a kurzust. E kurzusok összeállítása, illetve késôbbi tárolása, és az egyes részeik iránti érdeklődés indukálja azt, hogy erre a könyvtáros szakmának is reagálnia kell.

Az előbbiekben bemutatott képzési formák elterjedésében fontos szerepet játszik, a 2012-es OER-dekrétum (Open Educational Resources: Nyílt oktatási erőforrások) UNESCO általi elfogadása. A dekrétum abból indult ki, hogy a nyilt forráskódú szoftverek mintájára lehetséges az oktatáshoz kapcsolódó erőforrások (tananyagok, keretrendszerek, módszertanok, előadók, szellemi termékek) terjesztése, újrafelhasználása. Az elgondolás szorosan együtt mozog az kutatási eredmények nyílt hozzáférésével (open acces). Ezek rendszerezett tároláson alapuló elérhetőségének biztosítása is érinti a könyvtárakat.

\section{A könyvtárak és a közgyüitemények szerepe}

A könyvtárak három típusa alakult ki az informatikai fejlődés hatására: az elektronikus könyvtár, a digitális könyvtár, valamint a virtuális könyvtár. Míg az első csupán a metaadatokat tárolja elektronikusan, a másodikban már digitális tartalmakat olvashatunk, amelyeket elektronikus kereséssel érhetünk el, a harmadik esetében fizikai formájukan nem létező dokumentumok gyújteményéról beszélünk. ${ }^{67}$

A digitalizálás, amely kezdetben a tárolt javak tartalmát érintette -, de ma már eljutott a folyamatok és a tartalmak eleve digitális keletkezésig - új kihívás elé állítja a különböző gyüjteményi formák, így a könyvtárak működését is. Az oktatás terén megjelent digitális tananyagok ezen új kihívások közé tartoznak, több szempontból is:

1. digitális tartalmak, amelyeket tárolni és olvashatóságukat évek múltán is biztosítani kell (hardveres és szoftveres kihívások);

2. analóg és/vagy digitális építőkövekből jönnek létre, amelyek különböző helyekrôl származnak. E téren komolyan kell számolni a hitelesség kérdésével;

3. a felhasználók fizikálisan egyre kevésbé mobilak, átalakul a kutatás és a tanulás folyamata az ő viselkedésük szempontjából, jobban preferáltak az egykapus rendszerek (a felhasználót nem feltétlenül érdekli, hogy a keresett információt könyvtári, levéltári vagy múzeumi oldalon találja meg, ami fontos számára: a relevancia, a megtalálás átfutási ideje és a hitelesség).

A digitalizálás jelenlegi állapotával együtt jár egy újfajta közlési mód kialakulása, amely nem élőszóban zajlik, hanem különböző platformokon, ugyanakkor jellemzőinek egyike hasonlít az orálisan nem rögzített közlésekhez. Mindezek során számos adat keletkezik, az információk torzulnak, kialakulnak az álhírek. Ebben a helyzetben a könyvtári, levéltári, múzeumi gyűjtemények egyre inkább hiteles helyként múködnek, az általuk végzett gyűjtő, rendszerező, kereshetőséget biztosító szolgáltatások mellett az információk hitelességének garantálása is egyre fontosabb. Kérdés persze, az, hogy ennek mennyi 


\section{NEMES LÁSZLÓ}

az értéke, a társadalom vállalja-e a közgyűjtemények fenntartásával ennek az egyéni felhasználók felé történő olcsó biztosítását vagy sem.

Nem globálisan nézve, hanem a különböző tananyag-készítési folyamatok szempontjából az egyes tananyagok alkotóelemeinek tárolására, újrahasznosítására szintén a könyvtári szolgáltatások adhatnak egyfajta működőképes választ. A tananyagok önmagukban is tárolhatók, de a különböző szabványok megegyeznek abban, hogy azokat egyre kisebb elemi, de még önálló jelentéssel bíró egységekre (learning objectekre), illetve már önálló jelentéssel nem bíró elemekre (learning assetekre) ${ }^{8}$ bontják, ezek lehetnek képek, videók, szöveges tartalmak.

Ugyanakkor az is látható, hogy a felhasználók részéről a digitálisan elérhető tartalmak és azok leíró adatai számítanak, de hogy milyen típusú gyűjteményből valók, már másodlagos. Ez olyan egykapus rendszereknek kialakításnak kedvez, amelyek aggregálják a különböző gyüjteményeket és ugyanazzal a kereső felülettel teszik lehetővé azok használatát.

\section{Gyakorlati példa}

Egy gyakorlati példán illusztrálom a távoktatás és a könyvtárak kapcsolatát. A közszolgálatban dolgozó tisztségviselők számára jogszabályi kötelezettség a rendszeres továbbképzés. Az érintettek létszáma meghaladja a százezer főt, földrajzilag nem egy helyről érkeznek (nincs ideálisan közeli helyszín a közösség többsége számára, kivéve a fővárosban dolgozókat, akik száma a legjelentősebb), a napi munkavégzés mellett sokaknak nehezen menedzselhető a továbbképzés miatti rendszeres és több napos hiányzás. Ennek okán a képzésekért felelős felsőoktatási intézmény két irányból közelítette meg a kérdést, amelyeknek könyvtár- és információtudományi relevanciái a következőkben foglalhatóak össze.

Nemzeti Közszolgálati Tudásportál létrehozása, amelynek a célja, hogy a képzéseken résztvevők, valamint azok, akik nem vesznek részt egyetlen képzésen sem, elérjék a közigazgatás-tudomány legfrissebb szakirodalmait, valamint a kutatásokhoz kapcsolódó primer források egy részét is. Így ez a portál integrálja magában a könyvtári és a levéltári jellegú dokumentumokat egyaránt. Egy ún. Online Lexikon révén teszi levehetôvé, hogy egy-egy fogalom hiteles, az adott pillanatban valid definícióját, ill. tudományterületenkénti értelmezését elérjék a felhasználók. Az Online Lexikon alapját adó fogalomtár összekötő kapocsként szolgál mind a könyvtári katalógus, mind a zárt, a képzések hallgatói számára elérhető online tananyagok irányába. A fogalomtárban a definíciókon túl relációs kapcsolatokat is rögzítettek.

A képzés hallgatói számára készülő tananyagok speciális keretrendszerben, a Pro Bono portálban érhetőek el. A tananyag-összeállítás jelenleg is módszertani fejlesztés alatt áll. Így könyvtári szempontból több fókusszal rendelkezünk. Egyrészt a korábbi tananyagok formai leírására és tartalmi feltárására kell módszertant kidolgozni annak érdekében, hogy a későbbiekben is elérhetőek legyenek. Másrészt az új típusú tananyag 
készítői, tanulási tervezői számára biztosítani kell, hogy a tananyagok építő elemei rendszerezetten elérhetőek legyenek. A fogalomtárban tárolt fogalmak tárgyszóként való alkalmazása ezt a célt szolgálja, ugyanakkor a tananyagokban található fogalom-definíciók is erre a forrásra fognak hivatkozni.

A két megközelítés - bár egy felhasználói kört céloz meg -, azoknak mégis eltérô állapotára fókuszál. Míg a Tudásportál esetében a tartalom-előállítási folyamat végén létrejött művek rendszerezése és szolgáltatása a feladat, kiegészítve a fogalmak és e múvek tartalmi elavulásának követésével, addig az elektronikus környezetben futó tananyagokat támogató rendszer a tartalom-előállítási folyamat részeként is szolgáltatja a folyamathoz szükséges adatokat, felhasználói köre pedig kiegészül az előállítási folyamat részvevőivel. Így a könyvtári rendszerek egy újabb integrációs lehetőségét teszteljük.

\section{Jegyzetek és irodalom}

1. HALÁSZ Gábor: Az oktatási rendszer. Budapest, Műszaki Kiadó, 2001. 10-25. p.

2. FRANK Róza: Távoktatás és a közkönyvtárak szerepe. = Tudományos és Múszaki Tájékoztatás, 46. évf. 3. sz. 1999. 101-106. p. Forrás: http://tmt-archive.omikk.bme.hu/show_news. html@id=1868\&issue_id=9.html [2018. március 10.]

3. Uo.

4. CZEGLÉDI László: E-learning könyvtár: a fogalom és a megvalósítás. = Tudományos és Mưszaki Tájékoztatás, 54. évf. 8. sz. 2007. 353-358. p. Forrás: http://epa.oszk.hu/03000/ 03071/00002/pdf/EPA03071_tmt_2007_08.pdf [2018. március 10.]

5. FORGÓ Sándor - HAUSER Zoltán - KIS-TÓTH Lajos: A blended learning elméleti és gyakorlati kérdései. 4. p. [online/elektronikus dokumentum] Forrás: https://nws.niif.hu/ ncd2005/docs/ehu/029.pdf 2018. március 16. [2018. március 10.]

6. TÓVÁRI Judit: Az elektronikus, digitális, virtuális könyvtárak dokumentumainak feltárása. [elektronikus dokumentum]. Távoktatási tananyag. Bíróképző Akadémia, 2009.

7. TÓVÁRI Judit: Digitális archívumok forrásainak felhasználása az oktatásban (előadás). Forrás: http://slideplayer.hu/slide/11699105 [2018. március 10.]

8. FAZEKAS Gábor - KOCSIS Gergely - BALLA Tibor: Elektronikus oktatási környezetek. Debreceni Egyetem, 2014. Forrás: http://www.tankonyvtar.hu/hu/tartalom/tamop412A/ 2011-0103_10_elektronikus_oktatasi_kornyezetek/ch04.html [2018. március 10.]

Nemes László 2010-ben szerzett diplomát az ELTE informatikus könyvtáros, 2013-ban pedig a felsőoktatás- és tudománymenedzsment szakán, 2016-ban sikeres államvizsgát tett levéltár szakon. Az ELTE Irodalomtudományi Doktori Iskola Könyvtártudományi Doktori Programjának hallgatója. 2008 óta az ELTE Könyvtári Nap főszervezője, az első és a második Masters of Library and Information Science konferencia főszervezője. 2009-től a Magyar Információtudományi Alapítvány kuratóriumi elnöke. Jelenleg a Nemzeti Közszolgálati Egyetem számára e-learning tananyagok tárolását biztosító virtuális könyvtár kidolgozásának szakmai koordinációját végzi. 